\title{
DIREITOS INDIVIDUAIS E BENS COLETIVOS EM ROBERT ALEXY
}

\author{
INDIVIDUAL RIGHTS AND COLLECTIVE GOODS \\ IN ROBERT ALEXY
}

\author{
CRISTHIAN MAGNUS DE MARCO ${ }^{1}$ \\ JANAÍNA RECKZIEGEL ${ }^{2}$
}

\begin{abstract}
RESUMO: Este artigo propõe um estudo conceitual das categorias: direitos individuais e bens coletivos, com base na teoria de Robert Alexy. São analisados aspectos atinentes à colisão entre os direitos individuais e bens coletivos, suas relações e a precedência prima facie daqueles em face destes. Trata-se de estudo predominantemente bibliográfico, mas, com análise de dois julgados emblemáticos proferidos pelo Supremo Tribunal Federal, os quais possibilitam a visualização dos principais argumentos utilizados na ponderação dos direitos e interesses em jogo, bem como a utilidade da distinção conceitual.
\end{abstract}

PALAVRAS-CHAVE: Direitos Fundamentais; Direitos Individuais; Bens Coletivos.

ABSTRACT: This article proposes a conceptual study of the categories: individual rights and collective goods, based on the theory of Robert Alexy. The text analyzes the collision between individual rights and collective goods, their relations and precedence prima facie. It is a predominantly bibliographical study, but with analysis of two emblematic judged rendered by the Supreme Court (Supremo Tribunal Federal), which allow the visualization of the main arguments used in balancing the rights and interests at stake, and the usefulness of the conceptual distinction .

KEYWORDS: Fundamental Rights; Individual Rights; Collective Goods.

Artigo recebido em 06.05.2014. Pareceres emitidos em 11.09.2014 e 15.09.2014.

Artigo aceito para publicação em 19.01.2015.

${ }^{1}$ Doutor em Direito pela Pontifícia Universidade Católica do Rio Grande do Sul, Porto Alegre. Mestre em Direito pela Universidade Federal de Santa Catarina, Florianópolis. Professor do Programa de Pós-Graduação em Direito da Universidade do Oeste de Santa Catarina, Chapecó. Advogado.cristhian.demarco@unoesc.edu.br

${ }^{2}$ Doutora em Direitos Fundamentais e Novos Direitos pela Universidade Estácio de Sá - Rio de Janeiro, capital. Mestre em Direito Público pela Universidade de Caxias do Sul, Rio Grande do Sul. Graduada em Ciências Jurídicas e Sociais pela Universidade do Oeste de Santa Catarina. Professora e Pesquisadora da Universidade do Oeste de Santa Catarina, Chapecó (UNOESC). Advogada e Professora Universitária. janaina.reck@gmail.com 
SUMÁRIO: Introdução; 1. Direitos Individuais e Bens Coletivos; 1.1 O Conceito de Direito Individual; 1.2 Teoria dos Princípios; 2. Bens Coletivos; 3. Das Relações entre Direitos Individuais e Bens Coletivos; 4. Da Ponderação; 5. Da Precedência prima facie dos Direitos Individuais sobre os Bens Coletivos; 6 . Análise de Dois Casos decididos pelo Supremo Tribunal Federal nos quais é possível atribuir-se colisões entre Direitos Individuais e Bens Coletivos; Conclusão; Referências.

SUMMARY: Introduction; 1 . Individual Rights and Collective Goods; 1.1 The Concept of Individual Rights; 1.2 Theory of Principles; 2. Collective Goods; 3 . The Relationships between Individual Rights and Collective Goods; 4. The Weighting; 5. The prima facie Precedence of Individual Rights over Collective Goods; 6. Analysis of Two Cases decided by the Brazilian Supreme Court in which it is possible to find collisions between Individual Rights and Collective Goods; Conclusion; References.

\section{INTRODUÇÃO}

No presente artigo pretende-se realizar um estudo conceitual das categorias: direitos individuais e bens coletivos propostas por Robert Alexy. Aborda-se também a importância da ponderação na teoria do mesmo autor. Na segunda parte do texto, são analisados dois casos julgados pelo Supremo Tribunal Federal, nos quais se pretendeu aplicar a proposta dogmática de Alexy nos seus aspectos prescritivos (dimensão crítico-normativa) e descritivos (dimensão empírica).

Alexy afirma que os direitos individuais possuem uma precedência prima facie sobre os bens coletivos. Essa instigante proposição encontra-se inserida nas formulações analíticas de Robert Alexy (2010, p. 176) que aqui serão apresentadas na forma de estudo preliminar, visando fomentar o debate e 0 amadurecimento de ideias.

Trata-se de pesquisa bibliográfica. A metodologia empregada está direcionada à análise de conceitos e as suas relações; tarefa indispensável para a formação de uma estrutura semântica básica, com vistas à correção do discurso jurídico-dogmático e à possibilidade de diálogo (intersubjetividade). Não se pressupõe nessa tarefa, obviamente, a neutralidade do observador, nem uma separação entre sujeito-objeto, muito menos o encontro de respostas finais.

\section{DIREITOS INDIVIDUAIS E BENS COLETIVOS}

Alexy (2010, p. 176) sustenta que a relação entre bens coletivos e direitos individuais faz parte de um debate filosófico e jurídico que não quer terminar. Duas ordens de problemas são fundamentais, uma analítica (conceitual) e outra normativa (crítica). No aspecto normativo, exsurgem problemas relacionados às concepções de justiça, de estado e de sociedade. Pode-se dizer, na instância normativa, que só haverá possibilidade de consenso sobre

\footnotetext{
${ }^{3}$ Alexy (2008, p. 35) concebe a dimensão normativa como aquela encarregada de elucidar e criticar a práxis jurídica, especialmente a jurisprudencial. A questão central é partir do direito positivo e avaliar a correção das decisões nos casos concretos. Pode-se, assim, denominar-se essa dimensão, de dimensão da crítica.
} 
a dicotomia direito individual versus bens coletivos, se houver entendimento: sobre o que é justo, quais são as tarefas do estado e quais são os direitos e as obrigações da sociedade. Essas divergências irão se manifestar em diversos ramos do Direito.

No campo do Direito Criminal, por exemplo, há importantes divergências sobre a extensão da proteção da legislação penal sobre os bens jurídicos, especialmente quando se pretende alcançar bens coletivos no contexto do constitucionalismo contemporâneo ou transconstitucionalismo ${ }^{4}$. A eleição das condutas a serem consideradas criminosas ficará atrelada à compreensão daquilo que deve ou não ser considerado como bem jurídico, e, mais especificamente, um bem jurídico penal. Por conseguinte, a definição de crimes contra o meio ambiente, crimes contra a ordem econômica e crimes contra o sistema financeiro, por exemplo, passará pela discussão acerca do conceito de bem jurídico coletivo. ${ }^{5}$

Nas áreas cíveis, da mesma forma, o conceito de bem coletivo é bastante debatido, tendo recebido novos contornos no cenário contemporâneo. Para Mauro Capeletti (1977, p. 130) a sociedade atual é uma civilização complexa, que produz, troca, consome e conflitua em massa, buscando progressivamente o Poder Judiciário para a solução de conflitos coletivos. Emergiram daí novas categorias de proteção aos interesses coletivos em sentido amplo ou transindividuais, tais como: direitos ou interesses difusos, direitos ou interesses coletivos em sentido estrito e direitos ou interesses individuais homogêneos. ${ }^{6}$

Da processualística italiana colhe-se a consagrada distinção entre interesses individuais e interesses coletivos. Para Francesco Carnelutti (2004, p. 55) um interesse é uma posição favorável à realização de uma necessidade. Esse interesse será individual quando disser respeito a um único indivíduo ou, coletivo, quando concernir a muitos, vários ou todos os indivíduos.

Direitos e interesses são, portanto, categorias que merecem alguma distinção. A expressão direitos está nitidamente atrelada à concepção de Direitos Subjetivos, sejam eles individuas ou coletivos. Interesse, por seu turno, é a categoria preferida para reforçar o contexto da proteção de bens coletivos em sentido amplo (MANDELLI, 2013, p. 37), mas, também, podem significar pré-direitos, que ainda estão na esfera privada. De qualquer sorte, as expressões são utilizadas indistintamente tanto na Constituição brasileira (v.g. art. $8^{\circ}$, III, da Constituição da República de 1988) e na legislação infraconstitucional (v.g. art. 81, do Código de Defesa do Consumidor), sendo dispensável, ao nosso sentir, qualquer diferenciação na esfera processual

\footnotetext{
${ }^{4}$ Expressão utilizada por Marcelo Neves (2009) para significar o atual momento histórico vivido pelo constitucionalismo, num contexto de coexistência de normas nacionais e internacionais de proteção aos direitos humanos.

${ }^{5}$ Não está nos propósitos deste texto aprofundar o riquíssimo debate sobre bens jurídicos que ocorre no Direito Penal. A citação é apenas ilustrativa. Para maiores informações sobre a matéria, indica-se a tese de Doutorado de Fábio Romeo Canton Filho (2009).

${ }^{6}$ Para maior detalhamento conceitual dessas categorias, conferir (MANDELLI, 2013).
} 
protetiva de direitos coletivos. Talvez, o uso da expressão interesse facilite eventual tutela cautelar de bens coletivos, sobre os quais ainda não se tenha claramente a configuração de um direito.

Entrementes, o presente texto não pretende ingressar nas peculiaridades conceituais específicas das searas cível e penal. Tampouco se tenciona investigar o rico debate administrativo-constitucional das definições de interesse público, interesse privado e interesse geral. ${ }^{7}$ Os conceitos propostos por Alexy que a seguir serão analisados encontram-se no quadrante da filosofia do direito, sendo fundamentais para que se possam distinguir (sem separar) os campos dos direitos individuais e dos bens coletivos ${ }^{8}$, proporcionando uma irradiação conceitual para todos os campos do direito.

No que tange ao aspecto analítico, Alexy (2008 e 2010) sustenta que existe muita confusão na solução dos problemas normativos, em razão da falta de clareza sobre os conceitos de bem coletivo e direito individual. Em razão disso, propõe buscar essa clareza (a) conceituando direito individual e bem coletivo, (b) relacionando esses dois conceitos e (c) apresentando teses normativas sobre essas relações (ALEXY, 2010).

\subsection{Conceito de Direito Individual}

O conceito de direito individual repousa sobre duas colunas: 1) um modelo-três-graus de direitos individuais, e 2) uma teoria dos princípios.

Para Alexy (2010, p. 176), a falta de clareza na distinção entre três posições jurídicas para direitos individuais é o motivo para a existência de litígios na sua compreensão. Por isso, explica que o seu modelo-três-graus deve distinguir: a) fundamentos para direitos individuais, b) direitos individuais como posições e relações jurídicas e c) o poder ser imposto de direitos individuais.

Os fundamentos para direitos individuais não se confundem com os próprios direitos individuais. Direitos individuais podem estar justificados tanto em bens individuais como em bens ou interesses coletivos. Ou em ambos. O direito de propriedade é um exemplo disso. Pode basear-se no interesse do titular (Ihering) ou na liberdade de vontade (Windsheid) de um lado e, de outro, na efetividade da ordem econômica, ou em ambas. Assim, para que não haja confusão entre direitos individuais e fundamentos para direitos individuais,

\footnotetext{
${ }^{7}$ Para Schmidt-Assmann (2003, p. 166), os interesses públicos estão orientados diretamente para o interesse geral. Mas, não se confundem com eles. Pois, só estão orientados ao interesse geral na medida em que se preocupam com a comunidade. Os interesses privados são legítimos e constitucionalmente garantidos, mas, devem ser estágios da formação paulatina de um interesse geral.

${ }^{8}$ Como se percebe, bens e interesses são categorias facilmente intercambiáveis em razão da relação inafastável entre elas. Nas traduções da Teoria dos Direitos Fundamentais de Robert Alexy (a) Virgílio Afonso da Silva traduz o original, para interesses coletivos, (b) Ernesto Galzon Valdés traduz como bienes colectivos, e (c) Julian Rivers traduz como collective interests. Alexy apresente a seguinte distinção entre bens e interesses: interesse é uma relação existente entre o indivíduo ou a coletividade e aquilo que pode ser denominado de bem, individual ou coletivo. Bem é o objeto de valor jurídico.
} 
estes devem ser considerados todos aqueles pertencentes ao particular. (ALEYX, 2010, p. 177).

Para Alexy (2010, p. 178), o conceito de direito individual é identificado, nesse aspecto, com o conceito de direito subjetivo, o qual já está bastante ambientado na dogmática jurídica. Assim, todos os direitos individuais são direitos subjetivos e todos os direitos subjetivos do particular são direitos individuais.

Verifica-se, então, que os fundamentos para os direitos individuais podem ser: o interesse, a vontade e os bens coletivos (unidos ou dissociados). Essas categorias necessitam, todavia, de conceitos antropológicos e axiológicos, enquanto que o conceito de direito individual é puramente deontológico (ALEXY, 2010, p. 178).

Num segundo grau, os direitos consistem em posições e relações jurídicas. As posições jurídicas, que podem ser aqui designadas como direitos, dividem-se em a) direitos a algo, b) liberdades e c) competências. Essas posições possuem uma funcionalidade prática e teórica por meio das relações estabelecidas entre a) um titular do direito, b) o objeto do direito e c) o destinatário. As relações mais complexas ocorrem quando há união entre liberdades e direitos a algo (ALEXY, 2010, p. 179). Podemos exemplificar tal complexidade citando as situações em que é necessária alguma prestação material para que a pessoa possa exercer livremente o seu direito ao desenvolvimento da personalidade.

Por fim, Alexy (2010, p. 180) entende ser necessário distinguir-se a posição jurídica do titular de um direito individual e sua relação com as competências e permissões, ou seja, o poder de imposição do direito. Um direito subjetivo, para Alexy, não é o poder fazer valer o cumprimento de um dever. O direito subjetivo é o fundamento do poder para fazer valer um direito. Não se confunde com ele, portanto.

\subsection{Teoria dos Princípios}

Ao lado do modelo-três-graus para os direitos individuais, entende Alexy que o conceito de direito individual pressupõe também uma teoria dos princípios dos direitos individuais.

$\mathrm{Na}$ teoria dos princípios apresentada por Alexy (2008 e 2010), é essencial a distinção entre regras e princípios. Princípios são mandamentos de otimização, ou seja, são mandados para que algo seja realizado de maneira ótima, dentro das possibilidades fáticas e jurídicas existentes. Regras são mandados definitivos. Simplesmente podem ou não podem ser cumpridos.

Não é difícil encontrar na literatura jurídica brasileira, fortes críticas à Alexy e sua teoria dos princípios. Lênio Streck, por exemplo, assevera que distinção entre regras e princípios ignora o que ele chama de dupla estrutura da linguagem, isto é, a existência de uma estrutura na qual nos movemos logicamente e a outra, (sempre difícil de explicar) na qual habita o universo 
da pré-compreensão. Ao proceder "como se as regras estivessem ligadas à subsunção [...] e os princípios [...] às teorias argumentativas.", Streck (2006, p. 197), entende que Alexy está produzindo uma distinção metafísica que ignora as limitações do processo de atribuição de sentido decorrente das pré-compreensões e da antecipação de sentido que todos estão submetidos.

Porém, não parecer que Alexy ignore os avanços da filosofia hermenêutica, muito menos da filosofia da linguagem. A dogmática de Alexy, contudo esteja preocupada com clareza conceitual, sugere, desde as primeiras páginas, uma abertura para o desvelamento de sentidos e para a reconstrução do caminho percorrido pelo intérprete. Nem de perto e nem de longe, Alexy parecer acomodar-se ao modelo lógico-subsuntivo, típico da metafísica positivista. Para ele, tanto as regras ${ }^{9}$ como os princípios resultam de um processo discursivo/argumentativo. Isso decorre de um dever de honestidade, alteridade e intersubjetividade. Trata-se de um objetivo a ser cumprido no nível discursivo, ou seja, no patamar daquilo que é humanamente possível, dialogável. Pensar-se na discussão de fundamentos em outro nível, que não possa ser posto às claras e com isso propiciar um jogo de razões e contrarrazões, é pensar-se em algo interessante na busca de fundamentos teológicos; talvez filosóficos. Porém, Alexy está preocupado com a possibilidade racional (talvez o mais racional possível) de decidirem-se casos concretos, num Estado Democrático de Direito. Nesse aspecto, parece que o autor cumpre a sua missão.

Alexy (2010, p. 180) elogia a distinção realizada por Dworkin entre regras e princípios $^{10}$, porém, entende que a proposição formulada pelo filósofo americano, segundo a qual os direitos seriam trunfos sobre decisões políticas estabelecidas para o bem da comunidade ${ }^{11}$, é muito rudimentar. Isso levaria a uma conclusão de que os direitos individuais sempre seriam mandados definitivos contra os bens coletivos.

Na qualidade de princípios (mandados de otimização), os direitos individuais certamente entrarão em colisão com bens coletivos e/ou com outros direitos individuais. Por isso, antes de falar-se sobre os postulados práticos para a argumentação jurídica - que Alexy sugere sejam utilizados nesses casos - é importante verificar-se também o conceito alexyano de bem coletivo.

\section{BENS COLETIVOS}

Alexy (2010, p. 181) sustenta que é mais fácil exemplificar do que conceituar bens coletivos. São exemplos: segurança, prosperidade, meio ambiente equilibrado e alto nível cultural. São três as dimensões que transformam esses valores em bens coletivos: (1) a sua estrutura não distributiva; (2) o seu status normativo e; (3) a sua fundamentação.

\footnotetext{
${ }^{9}$ Para Alexy (2008, p. 108) as regras são razões definitivas. Disso se dessume que Alexy não tem em mente um conceito ontologizante e metafísico de regra. As regras são, portanto, razões para "um determinado juízo concreto".

${ }^{10}$ Cf. DWORKIN (1978).

${ }^{11}$ Cf. DWORKIN (2000).
} 
A não distributividade é uma característica que distingue os bens coletivos dos direitos individuais. Deve-se entender por não distributividade, a impossibilidade de decompor esse bem em partes. É impossível fracionar um bem coletivo e entregar suas partes aos indivíduos.

A segurança pública, por exemplo, é um valor que se apresenta como um bem coletivo. Esse bem axiológico-valorativo, quando determinado pelo ordenamento jurídico, recebe uma característica deontológica, assumindo status normativo. Portanto, se um bem não pode ser repartido entre os indivíduos, mas sua realização é determinada por uma regra (mandado definitivo) ou por um princípio (mandado de otimização), trata-se de um bem coletivo. Nesse status normativo um bem coletivo ele deixa de ser um mero interesse (dimensão antropológica) ou valor (dimensão axiológica) para assumir um caráter de dever jurídico (deontológico), ou seja, norma (ALEXY, 2010, p. 181).

Destarte, o problema da fundamentação dos bens coletivos é um problema de fundamentação das normas. Tendo em vista que se torna muito problemático o estabelecimento de consensos na discussão sobre os fundamentos de determinado bem coletivo - assim como para os direitos individuais -, é preferível que o conceito de bem coletivo esteja, então, desvinculado do seu fundamento. É suficiente para sua caracterização a questão da não distributividade.

\section{DAS RELAÇÕES ENTRE DIREITOS INDIVIDUAIS E BENS COLETIVOS}

A partir do quadro apresentado acima, Alexy (2010, p. 184 e ss) propõe quatro teses quanto às possíveis relações conceituais entre direitos individuais e bens coletivos.

A primeira tese trata de uma relação meio-finalidade, sendo sua proposição: que "todos os direitos individuais são exclusivamente meios para bens coletivos". Para Alexy (2010, p. 187), essa tese só é possível conceitualmente, já que, na realidade, isso conduziria a um sistema normativo que não levaria o particular a sério.

A segunda tese também trata da relação meio-finalidade, propondo que: "todos os bens coletivos são exclusivamente meios para direitos individuais". Essa tese possibilita duas conclusões radicais. Ou terminaria por concluir que bens coletivos não existem - pois, "para tudo aquilo que o estado cria em coisas úteis, agradáveis e valiosas simplesmente direitos individuais correspondentes são encontrados como suas finalidades" - ou que os direitos coletivos são apenas (meramente) meios para a realização de direitos individuais. Nesse último caso, a teoria normativa seria problemática, já que as soluções para os problemas jurídicos dependeriam sempre de uma unanimidade de entendimento sobre todos os bens coletivos. (ALEXY, 2010, p. 188).

A terceira tese propõe uma relação de identidade entre direitos individuais e bens coletivos: "todos os bens coletivos são idênticos com estados, nos 
quais existem direitos individuais e são cumpridos." Para o autor, não há uma identidade geral ou especial entre eles, ou seja, os direitos coletivos não são apenas uma classe dos direitos individuais, em razão da sua característica de não fracionamento (ALEXY, 2010, p. 189).

A quarta proposição invoca uma relação de independência entre direitos individuais e bens coletivos, sustentando que não há entre eles relações de meio-finalidade nem relações de identidade. Essa tese também deve ser refutada, já que, é impossível admitir que em nenhum caso, haja uma relação de identidade ou de meio-finalidade entre direitos individuais e bens coletivos.

Assim, conclui Alexy (2010, p. 191) que essas formulações fortes podem facilmente ser refutadas. Todas elas tornam-se, entretanto, interessantes, se forem formuladas em versões fracas, que admitam possibilidades.

Essas relações entre direitos individuais e bens coletivos conduzem à conclusão de que direitos individuais não se reduzem a interesses coletivos, sob pena de não se levar a sério o particular. O contrário também é verdadeiro, bens coletivos não se reduzem a interesses particulares.

Alexy (2010, p. 194) propõe, ainda, que, em regra, apresentar algo como bem coletivo demanda um modo coletivo de imposição, ou seja, o processo político de um sistema democrático. $\mathrm{E}$, o fato de não existirem direitos individuais que correspondam aos bens coletivos, não significa que os bens coletivos não existam.

A seguir, é importante verificar-se a importância dada por Alexy à ponderação dos princípios, como postulado para a solução prática de colisão de direitos individuais e bens coletivos.

\section{DA PONDERAÇÃO}

Em um sistema normativo democrático - que exige justificação - há tanto direitos individuais como bens coletivos com força própria (ALEXY, 2010, p. 194 e ss). Se tais direitos têm força própria e se apesentam na forma de princípios, é normal que, no funcionamento do sistema, esses direitos colidam ao serem otimizados. Assim, a solução para a colisão deverá ocorrer por meio da proporcionalidade, estabelecendo-se uma ordem de precedência entre os princípios em choque.

Quando o conflito for entre regras (mandados definitivos), a solução deverá receber o tratamento adequado, por meio do critério de validade/invalidade ou criando-se uma regra de exceção.

A ponderação dos princípios cria uma relação de primazia condicionada entre eles. Ou ordem de precedência. A ponderação relaciona os pesos relativos dos princípios envolvidos no caso concreto. Otimizar é realizar um princípio de maneira tão ampla quanto possível, de acordo com as condições fáticas e jurídicas. Isso quer dizer, então, que a realização dos princípios é sempre "relativa", nunca "absoluta". 
Para a realização da ponderação, Alexy (2010, p. 196) relata que, no direito alemão, estão contidas na definição de otimização, três princípios ${ }^{12}$ parciais, sendo os dois primeiros de ordem fática e um terceiro de ordem jurídica. O princípio ou máxima ${ }^{13}$ da adequação perquire sobre a adequação do meio empregado para a realização de um princípio. A máxima da necessidade - segunda fase da proporcionalidade, ainda de ordem fática - verifica as situações em que há mais de uma alternativa para a realização dos princípios em jogo, esclarecendo qual ou quais alternativas devem prevalecer. A terceira fase é denominada de máxima da proporcionalidade em sentido estrito, ou preceito de proporcionalidade, que não é de dimensão fática, senão jurídica. Essa etapa torna-se relevante quando "o cumprimento de um princípio não é possível sem o não cumprimento ou prejuízo do outro" (ALEXY, 2010, p. 196).

Para o autor em estudo, quando não for possível o cumprimento de um princípio sem que outro receba um peso menor, análise esta que será realizada na última fase da proporcionalidade, deve-se observar uma regra denominada de lei da ponderação, ou seja: "quanto maior é o grau do não cumprimento ou prejuízo de um princípio, tanto maior deve ser a importância do cumprimento do outro." (ALEXY, 2010, p. 196). Prosseguindo no raciocínio, Alexy (2008a, p. 111) sustenta que a lei da ponderação deve decompor-se em três passos:

Em um primeiro passo deve ser comprovado o grau de não cumprimento ou prejuízo de um princípio. A isso deve seguir em um segundo passo, a comprovação da importância do cumprimento do princípio em sentido contrário. Em um terceiro passo deve, finalmente, ser comprovado, se a importância do cumprimento do princípio em sentido contrário justifica o prejuízo ou não cumprimento do outro.

Essa estrutura, afirma Alexy, é neutra, formal. Sua importância está no esclarecimento dos graus de importância que se atribui a cada princípio, entrando em questão cada argumento possível. "Com isso, a argumentação é dirigida em caminhos que não existiriam sem a lei da ponderação". (2010, p. 197). ${ }^{14}$

\footnotetext{
${ }^{12}$ Há discrepância no uso dessa expressão, entre princípio, máxima, postulado, mas, o sentido que Alexy a emprega ficará claro no texto e na forma de sua aplicação.

${ }^{13}$ Em Alexy (2010), o tradutor Luís Afonso Heck traduziu os subprincípios da proporcionalidade como princípios. Já na Teoria dos Direitos Fundamentais (2008), o tradutor, Virgílio Afonso da Silva, preferiu o emprego da expressão "máxima", para distinguir as fases procedimentais da proporcionalidade do conceito de princípio (mandado de otimização) usado por Alexy. Humberto Ávila (2013) prefere denominar proporcionalidade e razoabilidade como postulados.

${ }^{14}$ Sobre esse argumento, não se pode deixar passar, nessa quadra do trabalho, que há ainda outras formas metodológicas de percorrer-se discursivamente o caminho intelectivo de uma tomada de decisão. Exemplo disso é a propostas de MacCormick (2006), que estabelece três requisitos para a fundamentação dos casos difíceis: a) universalidade; b) consistência e coerência; e c) consequências criadas pela decisão.
} 
O Supremo Tribunal Federal, vale dizer, não utiliza o princípio da proporcionalidade como norma metodológica trifásica para suas decisões, apesar de realizar, em alguns votos, análises de: adequação, necessidade e proporcionalidade em sentido estrito. A mais alta corte brasileira, como bem relata Luiz Roberto Barroso (2013) adota de forma intercambiável as expressões razoabilidade e proporcionalidade, abrigando, no entendimento do autor "os mesmos valores subjacentes: racionalidade, justiça, medida adequada, senso comum, rejeição aos atos arbitrários e caprichosos." (BARROSO, 2013, p. 328).

\section{DA PRECEDÊNCIA PRIMA FACIE DOS DIREITOS INDIVIDUAIS SOBRE OS BENS COLETIVOS}

Alexy (2010, p. 197) advoga a existência de uma precedência prima facie dos direitos individuais sobre os bens coletivos. Mas, segundo ele, essa precedência é tão fraca que não pode significar uma tendência ao individualismo político ou moral. Trata-se apenas de um conceito destinado a levar a sério os direitos dos particulares, sem implicar na impossibilidade de se eliminar uma posição de um particular em prol de um bem coletivo.

A consequência desse ponto de vista é a carga argumentativa maior, prima facie, em favor dos direitos individuais. Então, quando uma decisão for tomada a favor de direitos coletivos, exigem-se fundamentos que falem mais forte dos que aqueles dos direitos individuais.

Essa postura do autor alemão repercute também nos casos de colisão entre direitos fundamentais subjetivos e direitos objetivos (ordem objetiva de valores constitucionais). Para Alexy (2010, p. 210): "a relação entre a dimensão subjetiva e a objetiva dos direitos fundamentais diz que existe uma presunção em favor da dimensão subjetiva. Quem afirma que uma norma de direito fundamental tem um caráter meramente objetivo suporta, para isso, a carga argumentativa."

Vejamos, agora, na jurisprudência brasileira, algumas possibilidades de identificação de aplicações dos conceitos propostos por Alexy.

\section{ANÁLISE DE DOIS CASOS DECIDIDOS PELO SUPREMO TRIBUNAL FEDERAL NOS QUAIS É POSSÍVEL ATRIBUIR-SE COLISÕES ENTRE DIREITOS INDIVIDUAIS E BENS COLETIVOS}

Dois precedentes da jurisprudência do Supremo Tribunal Federal do Brasil ilustram muito bem a problemática até aqui enfrentada, conforme serão descritos e analisados abaixo.

O primeiro caso a ser analisado é o Habeas Corpus $n^{\circ} 71.373-4 / R S$, impetrado no STF contra a decisão do Tribunal de Justiça do Rio Grande Sul, que determinava a condução "sob vara" do cidadão José Antônio Gomes Pinheiro Machado, destinada à coleta de sangue para a realização de exame de DNA. O objetivo do exame era a comprovação da paternidade das gêmeas Thais Marques Rosa e Lívia Marques Rosa. O Tribunal de Justiça havia 
decidido que, nessa situação, o investigado deveria ser conduzido "sob vara" ao local da coleta do sangue, já que o corpo seria "objeto de direitos", não sendo cabível a invocação de direitos personalíssimos de disponibilidade sobre o próprio corpo. (BRASIL, 2003)

O STF, por maioria de votos, reformou a decisão do Tribunal de Justiça do Rio Grande do Sul, reconhecendo que, neste caso, o direito fundamental individual à integridade corporal e à intimidade deve ser respeitado. Todavia, como se verá adiante, nem todos os votos enfrentaram a questão sob a perspectiva dessa colisão entre direito individual e bem coletivo. Mas, é interessante perceber-se como a proposta conceitual de Alexy acima detalhada, parece descrever com pertinência o modo de condução do discurso dos julgadores, à medida que se referem à uma colisão de princípios. Para tanto, vale observar como cada Ministro discursou e ponderou os interesses em jogo.

O Ministro Francisco Rezek, relator do processo, afirmou que: "O direito ao próprio corpo não é absoluto ou ilimitado. Por vezes a incolumidade corporal deve ceder espaço a um interesse preponderante". [...] "Estou em que o princípio da intangibilidade do corpo humano, que protege o interesse privado, deve dar lugar ao direito à identidade, que salvaguarda, em última análise, um interesse também público." (grifos nossos). É bem verdade que o Ministro Rezek, em alguns momentos, debateu a matéria sob o prisma da colisão entre dois direitos individuais e, nesse caso, apontou como estando de um lado o direito individual à identidade genética do filho (sem, contudo, dizer qual é a previsão constitucional desse direito) e, de outro, o direito individual à intangibilidade do corpo humano (ou intimidade), estabelecida no artigo $5^{\circ}$, incido $X$, da Constituição Federal. Mas, também conduziu o seu raciocínio à constatação da existência de valores constitucionais atinentes à proteção à família, à criança e ao adolescente, valores estes que, segundo o relator, "observa-se uma superlativa atenção do legislador, a partir da Carta de 1988." Nesse sentido, mirando no artigo 227, da Constituição Federal, que afirma ser dever da família, da sociedade e do Estado assegurar dignidade à criança e ao adolescente, o relator invoca uma norma infraconstitucional, artigo 27, da Lei 8.069/90, Estatuto da Criança e do Adolescente, para admitir a existência de um direito personalíssimo à filiação. $O$ ministro vai além do texto infraconstitucional, e diz que o direito à filiação pressupõe um direito à identidade genética mediante exame de DNA, não comportando um reconhecimento meramente formal, decorrente da confissão ou revelia processual por parte do pai, por isso, estaria autorizando a coleta compulsória de sangue.

Certamente a anotação do artigo 227, CF, feita pelo relator, descreve uma dimensão objetiva dos direitos fundamentais, conformando o bem coletivo atinente à proteção à família, à criança e ao adolescente. Essa dificuldade de dizer categoricamente se o que está em jogo é uma ponderação entre dois direitos individuais ou um direito individual e um bem coletivo, reforça a tese de Alexy segundo a qual deve prevalecer uma diferenciação "fraca" entre as 
4 teses antes apresentadas, ou seja, bens coletivos e direitos individuais se encontram num ambiente de fundamentação recíproca e são distinguidos basicamente pelo caráter da não distributividade. Desse modo, haverá a identificação de um bem coletivo sempre que o seu caráter foi indivisível (não distribuível). O interesse em proteger-se a família, a criança e o adolescente, certamente encaixa-se nesse conceito, configurando-se como um bem coletivo. Mas, seria interessante tecnicamente se o juiz-decisor resolvesse entregar ao jurisdicionado uma resposta na qual ele ponderasse no jogo argumentativo, com clareza, ou um direito individual à identidade genética da criança, ou o bem coletivo constitucional, indivisível, de proteção à família, à criança, à infância e a adolescência, em face do direito à intimidade. Mas, nem sempre esse critério é seguido, o que não significa necessariamente num prejuízo argumentativo. No caso em tela, o Ministro Francisco Rezek explicita, como sua derradeira razão para indeferir o Habeas Corpus, o fato de que o direito individual à incolumidade física do impetrante não pode impedir o interesse individual da criança em saber a paternidade, já que este direito vem fundamentado num bem coletivo, por que "a Constituição impõe, como dever da família, da sociedade e do Estado, assegurar à criança o direito à dignidade, ao respeito, além de coloca-la a salvo de toda forma de negligência."

Os votos deste acórdão não seguem rigorosamente as três máximas da proporcionalidade, já que este procedimento não é seguido metodicamente pelo STF. Mas, diante das circunstâncias fáticas consideradas pelo Ministro, especialmente porque "a espetada" para a coleta de sangue, no seu entendimento, seria um sacrifício risível, diante da importância da realização de um exame de DNA, com 99,99\% de certeza do resultado, considerou-se que o bem coletivo que ampara o direito individual à filiação (ou identificação genética), merece prevalecer sobre o direito individual à intimidade.

Para o Ministro Carlos Veloso, que também votou pela denegação da ordem: "Trata-se de interesse que ultrapassa os limites estritos da patrimonialidade, possuindo nítida conotação de ordem pública." Assim, sustentou a existência de interesses morais em jogo, atinentes ao princípio da dignidade humana que a Constituição assegura à criança e ao adolescente. Nesse voto, houve citação do $\S 6^{\circ}$ do art. $227^{15}$, da Constituição da República, para sustentar essa dimensão objetiva do princípio da proteção à criança e ao adolescente, registrado na Carta Maior, vale repetir, como um bem coletivo.

O Ministro Carlos Veloso acrescenta que o interesse moral na dignidade humana é o fundamento de uma posição jurídica, portanto, um direito fundamental, criado pela Constituição de 1988, reconhecido por princípio da igualdade da filiação. Para o Ministro, então, do texto do artigo $227, \S 6^{\circ}, \mathrm{CF}^{16}$,

\footnotetext{
${ }^{15}$ Art. 227, § 60 $6^{\circ}$ da Constituição Federal: "Os filhos, havidos ou não da relação do casamento, ou por adoção, terão os mesmos direitos e qualificações, proibidas quaisquer designações discriminatórias relativas à filiação."

${ }^{16}$ Art. 227. É dever da família, da sociedade e do Estado assegurar à criança, ao adolescente e ao jovem, com absoluta prioridade, o direito à vida, à saúde, à alimentação, à educação, ao lazer,
} 
infere-se uma norma de igualdade de filiação que permite - com o objetivo de identificar-se a paternidade - que o suposto pai seja, inclusive, conduzido à força.

No concernente à análise fática, ponderou o Ministro que a recusa do impetrante em fazer o exame, fundada na incolumidade física, é "egoística" e afetada em proporção "ridícula". Esse foi, portanto, o teste da "necessidade" (segunda fase da proporcionalidade) realizado pelo Min. Carlos Veloso, tendo concluído que o Habeas Corpus deveria ser negado. Os Ministros Sepúlveda Pertence e Ilmar Galvão seguiram o voto do relator.

Inaugurando a divergência vencedora, o Ministro Marco Aurélio de Mello votou pela concessão da ordem: "[...] a Carta Cidadã consigna que são invioláveis a intimidade, a vida privada, a honra e a imagem das pessoas inciso I, do rol das garantias constitucionais (artigo $5^{\circ}$ ). Onde ficam a intangibilidade do corpo humano, a dignidade da pessoa uma vez agasalhada a esdrúxula forma de proporcionar a uma das partes, em demanda cível, a feitura de uma certa prova? O quadro é extravagante e em boa hora deu-se a impetração deste habeas-corpus."

O Ministro Marco Aurélio considerou relevante como aspecto fático, a dificuldade que ocorreria no momento da coleta do sangue, caso houvesse necessidade de imobilizar-se o réu contra a sua vontade à camisa de força para recolher-se o material necessário. Considerou, também, que a recusa do impetrante na realização do exame poderá ser interpretada processualmente a seu desfavor, sendo este um meio menos gravoso para atingir-se o mesmo resultado. Ainda, de forma importante, o Min. Marco Aurélio ofereceu outra leitura daquilo que foi deduzido como norma, a partir do suporte fático do bem coletivo pugnado nos votos anteriores. A proteção à família, à criança e ao adolescente, anteriormente invocados como princípios que devem prevalecer sobre o direito individual, agora são sustentados como não geradores de um interesse ou direito específico no reconhecimento da paternidade. O Min. Marco Aurélio afirma que ninguém é compelido pela ordem jurídico-constitucional a ver reconhecida a sua paternidade, por isso, trata-se de um direito individual. Ou seja, do suporte fático do bem coletivo: proteção à criança e ao adolescente, não se pode deduzir uma norma que determine a condução coercitiva para a coleta de sangue. Em outras palavras, pode-se dizer que o Ministro entendeu que o direito à intimidade é um limite à condução coercitiva para reconhecimento de paternidade. $E$, não bastasse isso, a norma fundamental objetiva do caput do artigo 227, CF, não contempla, necessariamente, a inafastabilidade do interesse privado ao reconhecimento da paternidade.

\footnotetext{
à profissionalização, à cultura, à dignidade, ao respeito, à liberdade e à convivência familiar e comunitária, além de colocá-los a salvo de toda forma de negligência, discriminação, exploração, violência, crueldade e opressão. (Redação dada Pela Emenda Constitucional ${ }^{\circ}$ 65, de 2010) [...] $\S 6^{\circ}$ - Os filhos, havidos ou não da relação do casamento, ou por adoção, terão os mesmos direitos e qualificações, proibidas quaisquer designações discriminatórias relativas à filiação.
} 
O Ministro Sydnei Sanches foi veemente ao discorrer sobre as circunstâncias fáticas: "Não me parece possível conduzir alguém a juízo e submetê-lo, contra a sua vontade, e até à força, à extração de sangue, como também não me parecia razoável forçá-lo à ejaculação, para obtenção de esperma, nem forçar alguém a fornecer elementos gráficos, de próprio punho, para exame grafotécnico. [...] Parece-me repugnar à natureza das coisas e à própria natureza humana compelir alguém, contra sua vontade, a servir como objeto de prova, com violação à intimidade até do corpo (art. $5^{\circ}$, inciso $\mathrm{X}$, da CF)." No mesmo sentido, o Ministro Néri da Silveira gizou a inadequação do meio empregado para a produção da prova, com as seguintes palavras: "O que considero, aqui, em debate, não é bem esse resultado da ação cível, mas, sim, questão concernente à liberdade e aos direitos individuais. Ninguém pode ser constrangido, contra sua vontade, a um exame que implica extração de material hematológico de seu corpo."

O Ministro Moreira Alves reforçou o argumento exposto pelo Ministro Marco Aurélio, afirmando que: "[...] o direito à investigação de paternidade é um direito disponível [...]." Logo, o suporte fático do bem jurídico: proteção à família à infância e à adolescência, não necessariamente obriga que o indivíduo tenha a sua paternidade formalmente reconhecida.

O Ministro Octavio Gallotti enfrenta a questão com categorias muito próximas às que interessam nesse estudo (direitos individuais e bens coletivos), porém, ao que parece, no entendimento do Ministro, diferentemente da construção teórica da teoria dos princípios de Alexy, concebe que interesse público sempre deve preponderar sobre o interesse individual. Argumentou o julgador que, tanto o direito à investigação de paternidade como o direito à integridade física são direitos individuais. Nessa perspectiva, o caso não proporcionaria uma colisão entre um direito individual e um bem coletivo, mas, tão somente, uma colisão entre dois direitos individuais. Nesse aspecto o Ministro é taxativo: "É certo que não é meramente patrimonial o direito que se pretende ver declarado na ação de investigação de paternidade, mas também não é um direito indisponível. E é um direito individual, não corresponde ao interesse coletivo, como sucederia se se tratasse de um processo criminal, ou também na hipótese, aqui aventada, da vacinação, que responde à proteção de um interesse de saúde pública." Porém, o Ministro, em seu voto que infelizmente possui apenas uma página, não teve tempo de enfrentar quais seriam as diferenças e consequências práticas se o caso envolvesse um bem letivo. Mas, de qualquer sorte, deixa a entender, que, se o caso contemplasse um interesse coletivo, este deveria prevalecer sobre o direito individual, independentemente do sopesamento.

Do teor dos votos acima parcialmente transcritos, infere-se a adequação das proposições alexyanas sobre a importância de uma teoria dos princípios para a análise jurídica de direitos individuais e dos bens coletivos. Depreende-se, ainda, que a argumentação, nesses casos, é invariavelmente reconduzida 
à ponderação dos direitos, interesses e bens jurídicos envolvidos no debatediscurso, mas isso nem sempre fica claro no teor dos votos. A proposta de Alexy oferece maior clareza no debate argumentativo, evitando que algumas expressões, tais como: bens ou interesse coletivo, bem público, interesse público ou, ainda, interesses morais, sejam utilizadas com feição meramente retórica. Parece-nos que a adoção mais uniforme de significados para as categorias direitos individuais e bens coletivos, dentro da teoria dos princípios (que relativiza todos os princípios), propiciaria um controle intersubjetivo maior do verdadeiro alcance dos discursos, valorizando o jogo de argumento e contra-argumento para fundamentação das premissas que embasam as decisões judiciais.

Outro caso emblemático, que proporciona, inclusive, mais nítida distinção, relativamente à colisão discursiva entre direitos individuais e os bens coletivos, foi tratado pelo Supremo Tribunal Federal na Reclamação $n^{\circ}$ 2.040-1. O caso ficou conhecido na mídia nacional como "caso Glória Trevi." A famosa cantora Mexicana estava sendo acusada em seu país por corrupção de menores. Escondeu-se no Brasil, mas foi encontrada e posteriormente presa na carceragem da Polícia Federal, local em que alegou ter sido estuprada e engravidada. Todos os agentes da Polícia Federal lotados naquela instituição foram indiciados. $\mathrm{Na}$ investigação, todos os policiais forneceram material genético voluntariamente. Faltava apenas o material genético da vítima, todavia, esta não autorizou a feitura da prova.

Para esclarecer os fatos, o juiz da $10^{\mathrm{a}}$ Vara Federal do Distrito Federal determinou a realização de exame de DNA com o material colhido da placenta da cantora, após o parto. Houve recurso e o caso chegou ao Supremo Tribunal Federal, travando-se debate sobre a possibilidade ou não da realização de exame genético contra a vontade da cantora. Enfim, exame foi autorizado pelo STF apenas com um voto contrário, proferido pelo Ministro Marco Aurélio de Mello, que se valeu do mesmo argumento referido no caso anterior. Em síntese, os Ministros seguiram o argumento do relator, Ministro Néri da Silveira, resumidos nos parágrafos finais do voto:

[...] há, destarte, em confronto com o alegado direito da reclamante a preservar a identidade do pai de seu filho, "o interesse do Estado em tutelar bens jurídicos constitucionais, como "moralidade administrativa" (art. 37, caput, da CF/88), "persecução penal pública" (art. 129, I, da CF/88) e "segurança pública" (art. 144, § 1, 1 , da CF/88). Ora, todos esses aspectos que se acrescem, como bens jurídicos da comunidade [...], ao direito fundamental à honra (art. $5^{\circ}, \mathrm{X}$ ) já examinado, estão a autorizar se estabeleça restrição, no caso concreto, ao invocado direito à intimidade da reclamante. Cumpre observar, de outra parte, que isso acontecerá sem invasão atual à sua integridade física, ou do filho há pouco nascido, eis que o exame de DNA se fará com material da placenta do filho da reclamante, que se encontra recolhida no Hospital, por decisão judicial". 
Com essa decisão, comprovou-se que o pai da criança era o próprio empresário e amante da cantora, o senhor Sergio Andrade. Como se deu a gravidez dentro do cárcere, ainda é fato não esclarecido.

O trecho do voto do Ministro Neri da Silveira é preciso ao apontar os bens coletivos garantidos em enunciados constitucionais, acompanhando, com isso, a distinção entre bens coletivos e direitos individuais.

Com efeito, percebe-se que houve uma inversão de precedência ${ }^{17}$ entre direito individual e bem coletivo nos casos HC 71.373-4 e RCL 2.040-1. Quais seriam, então, as diferentes condições que justificaram a mudança? Pelo que se infere dos votos, a circunstância decisiva para a alteração da precedência foi a gravidade da intervenção no direito fundamental à intimidade. No HC 71.373-4, os Ministros consideraram "esdrúxula" a situação em que haveria a necessidade de colher-se à força o material genético do suposto pai, réu da ação de investigação de paternidade. Já na RCL 2.040-1, importou o fato que a placenta da ré do processo crime estava cautelarmente acomodada em recipiente próprio, aguardando a realização de um exame, sem que, para isso, houvesse a necessidade do uso de alguma força física contra a parte do processo. Obviamente que a simples coleta de material genético, sem o consentimento da pessoa, mesmo sem violência, parece violar, a priori, a intimidade. Todavia, na decisão do STF, as circunstâncias do caso exigiram que os interesses coletivos: "moralidade administrativa" (art. 37, caput, da CF/88), "persecução penal pública" (art. 129, I, da CF/88) e "segurança pública" (art. 144, § $1^{\circ}$, I, da CF/88), acumulados ${ }^{18}$ (ou concorrentes), prevalecessem sobre o direito individual.

Então, como se pode perceber dos argumentos apresentados nos votos dos Ministros do Supremo Tribunal Federal, a precedência dos direitos fundamentais individuais é uma precedência "fraca", conforme o conceito de Alexy e, só pode ser definida, em termos discursivos, por meio da ponderação dos direitos e bens em colisão. Essa precedência, que em termos teóricos, exige maior carga argumentativa para o estabelecimento da precedência de um bem coletivo sobre o direito individual, tem um objetivo substancial que é: levar a sério os direitos do indivíduo.

Nota-se ainda, da análise dos julgados, que, para a realização da ponderação entre um direito individual e um bem coletivo, não necessariamente é percorrido o método trifásico da proporcionalidade como esquema metodológico de motivação da decisão. Todavia, verifica-se que, em geral, há um compromisso dos julgadores em fundamentar as premissas fáticas e suas consequências no mundo prático, bem como, percebe-se nos votos, a realização de um balanceamento dos interesses jurídicos em jogo. ${ }^{19}$

\footnotetext{
17 Maiores detalhes sobre o estabelecimento de uma lei de colisão para as condições de precedência entre princípios cf. Alexy (2008, p. 97).

${ }^{18}$ Sobre a concorrência de direito, cf. Canotilho (2003, p. 1268).

${ }^{19} \mathrm{O}$ presente artigo não teve por objetivo sindicar a lógica ou as falácias dos argumentos
} 
Independentemente da utilização da conhecida fórmula do peso proposta por Alexy ou do exame trifásico da proporcionalidade, perpassam em todos os votos, argumentos relativos (1) aos princípios em colisão; (2) à intensidade da intervenção; e (3) o grau de certeza das premissas fáticas e jurídicas e suas consequências práticas.

Assim, realizada essa breve análise dos dois precedentes da jurisprudência brasileira, é necessário finalizar este artigo registrando-se um aspecto dos conceitos de direito individual e bem coletivo de Alexy e da sua Teoria dos Direitos Fundamentais, que poderia ser alvo de críticas, a saber, o fato de ele embasado seus estudos no acervo jurisprudencial do Tribunal Federal da Alemanha. Entretanto, como se pode constatar ao longo deste estudo, as formulações teóricas e conceituais de Robert Alexy encontram ressonância na prática do Supremo Tribunal Federal brasileiro, com algumas variações, confirmando a percepção descritiva realizada pelo jurista alemão. Isso decorre, muito provavelmente, da predominância do ideal de constitucionalismo contemporâneo a partir pós-gerra, nas democracias liberais.

Por fim, sem olvidar da necessidade de respeitarem-se as peculiaridades históricas e as categorias dogmáticas já consagradas no ordenamento brasileiro, não podemos deixar de finalizar este artigo, sem apresentar a nossa consideração final. Assim, percebemos que o desenvolvimento dogmático das categorias aqui estudadas: bem coletivo e interesse individual, propostos por Alexy, permite boas balizas para a análise do discurso empregado nas decisões judiciais sobre princípios constitucionais.

\section{CONCLUSÃO}

Verificou-se na exposição acima, que Alexy advoga a existência de uma precedência prima facie dos direitos individuais sobre os bens coletivos. Mas, segundo ele, essa precedência é tão fraca que não pode significar uma tendência ao individualismo político ou moral. Trata-se apenas de um conceito destinado a levar a sério os direitos dos particulares, sem implicar na impossibilidade de se eliminar uma posição de um particular em prol de um bem coletivo.

A consequência teórica e prática desse ponto de vista é a carga argumentativa maior, prima facie, em favor dos direitos individuais. Então, quando uma decisão for tomada a favor de direitos coletivos, exigem-se fundamentos que falem mais forte dos que aqueles dos direitos individuais.

Partindo-se dessas premissas, não foi o objetivo desse artigo verificar propriamente o debate acerca das pré-compreensões ou preconceitos contidos na estrutura dogmática proposta por Alexy, ou dos votos dos Ministros do Supremo Tribunal Federal, para os casos de colisão entre direitos individuais e bens coletivos. Mas, sim, verificar se a estrutura conceitual proposta pelo jusfilósofo encontra respaldo nos casos emblemáticos citados acima.

apresentados nos votos dos julgamentos transcritos. Essa seria outra tarefa; também possível. O objetivo do texto está descrito na introdução. 
Disso tudo, dessume-se que as decisões analisadas não adotam, em todos os votos, exatamente as categorias utilizadas na doutrina de Alexy: direito individual, bem coletivo, ponderação, sopesamento, proporcionalidade, lei de colisão. Todavia, é fácil perceber que esses conceitos estão presentes em maior ou menor grau no jogo de razões e contrarrazões que fazem parte do processo de motivação da decisão. Por isso, a dogmática jurídica proposta por Alexy é ao mesmo tempo descritiva e crítico-normativa, proporcionando clareza conceitual e cooperando sensivelmente na avaliação dos fundamentos das decisões judiciais sobre direitos fundamentais.

\section{REFERÊNCIAS}

ALEXY, Robert. Constitucionalismo Discursivo. Tradução de Luís Afonso Heck. Porto Alegre: Livraria do Advogado, 2008a.

ALEXY, Robert. Direito, Razão, Discurso: estudos para a filosofia do direito. Tradução de Luís Afonso Heck. Porto Alegre: Livraria do Advogado, 2010.

ALEXY, Robert. Teoria de los Derechos Fundamentales. Tradução de Ernesto Garzón Valdés. Madrid: Centro de Estudios Constitucionales, 1997.

ALEXY, Robert. Teoria dos Direitos Fundamentais. Tradução de Virgílio Afonso da Silva. São Paulo: Malheiros, 2008.

ALEXY, Robert. Theory of Constitucional Rights. Tradução de Julian Rivers. Great Britain: Oxford, 2010.

ÁVILA, Humberto. Teoria dos Princípios: da definição à aplicação dos princípios jurídicos. São Paulo: Malheiros, 2013.

BARROSO, Luís Roberto. Curso de Direito Constitucional Contemporâneo: os conceitos fundamentais e a construção do novo modelo. 4. ed., São Paulo: Saraiva, 2013.

BRASIL. Supremo Tribunal Federal. Habeas Corpus 71373, Relator: Min. Francisco Rezek, Relator para acórdão: Min. Marco Aurélio, Tribunal Pleno, julgado em 10.11.1994, publicado em 22.11.1996, p. 45686. Disponível em: http://www.stf.jus.br/ portal/jurisprudencia/visualizarEmenta.asp?s1=000117236\&base=baseAcordaos. Acesso em: 29 abr. 2014.

BRASIL. Supremo Tribunal Federal. Reclamação no 2040, Relator: Min. Néri da Silveira, Tribunal Pleno, julgado em 21.02.2002, DJ 27.06.2003, p. 31. Disponível em: http://www.stf.jus.br/portal/jurisprudencia/visualizarEmenta.asp?s1=000098855\&base=base Acordaos. Acesso em: 29 abr. 2014.

CANOTILHO, José Joaquim Gomes. Direito Constitucional e Teoria da Constituição. 7. ed., Coimbra: Almedina, 2003.

CANTON FILHO, Fabio Romeu. A Valoração do Bem Jurídico Penal e a Constituição Federal de 1988: a evolução histórica das criminalizações no direito penal brasileiro. 2009. Tese (Doutorado em Direito Penal) - Faculdade de Direito, Universidade de São Paulo, São Paulo, 2009. Disponível em: <http://www.teses.usp.br/teses/disponiveis/ 2/2136/tde-03052010-153358/>. Acesso em: 17 out. 2014.

CAPPELLETI, Mauro. Formações Sociais e Interesses Coletivos diante da Justiça Civil. Revista de Processo, São Paulo, v. 2, nº 5, jan./mar. 1977.

CARNELUTTI, Francesco. Sistema de Direito Processual Civil. 2. ed., v. 1, São Paulo: Lemos \& Cruz, 2004. 
DWORKIN, Ronald. Taking Rights Seriously. Cambridge, Massachusetts: Harvard University Press, 1978.

DWORKIN, Ronald. Uma Questão de Princípio. São Paulo: Martins Fontes, 2000.

MACCORMICK, Neil. Argumentação Jurídica e Teoria do Direito. São Paulo: Martins Fontes, 2006.

MANDELLI, Alexandre Grandi. Processo Civil Coletivo: em busca de uma teoria geral. Porto Alegre: HS Editora, 2013.

NEVES, Marcelo. Transconstitucionalismo. São Paulo: Ed. WMF Martins Fontes, 2009. SARLET, Ingo. A Eficácia dos Direitos Fundamentais. 10. ed., Porto Alegre: Livraria do Advogado, 2009.

SCHMIDT-ASSMANN, Eberhard. La Teoria General del Derecho Administrativo como Sistema: objeto y fundamentos de la contrucción sistemática. Madrid: Marcial Pons, 2003.

STRECK, Lênio. Verdade e Consenso. Rio de Janeiro: Lumen Juris, 2006. 